\title{
Financial Performance of Hi-Tech Arai Private Limited
}

\author{
R. Ramamoorthy, G.Thilrukshan, Vimala D
}

\begin{abstract}
Based on information examination done on investigation of money related execution of Hi Tech Arai it very well may be presumed that the organization's in general budgetary exercises is attractive. Since the greater part of the crude materials are being imported, the organization needs to keep up a support stock for crisis cases. So a great deal of reserve is put resources into crude material inventories which at last influence the liquidity and benefit of the worry and consequently the liquidity pattern of the organization is expanding step by step which is a decent marker. The organization the greater part of incomes from the fare things of different nations. They will urging the fare to the remote counters. The money and bank parity of the organization is declining so the organization must have an eye on it. Installment to the lenders is deferred because of the inaccessibility of money close by. [1],[3],[5]
\end{abstract}

Keywords : cash,analysis,ratios

\section{INTRODUCTION}

An association's cash related conditions are of a significant stress to budgetary authorities and banks. As capital providers, examiners and leasers rely upon an association's cash related conditions for both the prosperity and advantage of their endeavors. Even more expressly, money related experts and banks need to know where their money went and where it is presently. The spending synopsis of fiscal record keeps an eye on such issues by giving point by point information about an association's advantage adventures. The fiscal record furthermore records an association's uncommon commitment and worth portions, in this way commitment and worth monetary experts can all the almost certain appreciate their relative positions in an association's capital mix. [2 ],[4],[6]

Cash related examination is a piece of the general business reserve work that incorporates taking a gander at real data to get information about the present and future budgetary prosperity of an association. Fiscal assessment can be associated in a wide combination of conditions to give business executives the information they need to choose fundamental decisions. The ability to grasp cash related data is essential for any business executive. Record is the language of business. Business destinations and targets are set in cash

Revised Manuscript Received on July 22, 2019.

R.Ramamoorthy, Department of MBA, Bharath Institute of Higher Education and Research, Tamilnadu, India. Email: ramamoorthy0071@gmail.com

G.Thilrukshan, Department of MBA, Bharath Institute of Higher Education and Research, Tamilnadu, India. Email: thilrukmba@ gmail.com

Vimala D, Department of CSE, Bharath Institute of Higher Education and Research, Tamilnadu, India. Email: vimalamuthu3@gmail.com related terms and their outcomes are assessed in budgetary terms. Among the aptitudes required to understand and manage a business is recognition with the language of reserve - the ability to examine and fathom cash related data similarly as present information as budgetary reports. [7],[ 9] ,[11]

The record work in business incorporates surveying money related examples, setting budgetary methodology, and making long-expand arrangements for business works out. It in like manner incorporates applying a plan of internal controls for the treatment of cash, the affirmation of offers, the apportioning of costs, the valuation of stock, and the underwriting of capital employments. In addition, the reserve limit expounds on these internal control systems through the availability of spending rundowns, for instance, compensation clarifications, fiscal records, and salary verbalizations. [8],[10],[12]

Finally, cash incorporates separating the data contained in spending answers to give gainful information to the officials decisions. Consequently, cash related assessment is only a solitary bit of the general limit of reserve, anyway it is a critical one. Finding the full significance contained in the declarations is at the center of budgetary examination. Perceiving how records relate to one another is a bit of cash related examination. Another bit of budgetary assessment incorporates using the numerical data contained in association declarations to uncover instances of activity that may not be clear externally. [13], [15] ,[ 17]

The advantage report follows the budgetary and physical resources that an association has open for business practices later on. It is fundamental to note, regardless, that the advantage report just records these benefits, and makes no judgment about how well they will be used by the officials. Consequently, the financial record is progressively useful in analyzing an association's present budgetary position than its typical execution. [14],[ 16], [18]

The standard parts of the money related record are assets and liabilities. Assets generally join both current assets (cash or partners that will be changed over to cash inside one year, for instance, obligation cases, stock, and prepaid expenses) and noncurrent (assets that are held for more than one year and are used in keeping up the business, including fixed assets like property, plant, and equipment; whole deal adventures; and insignificant assets like licenses, copyrights, and charitableness). Both the total of focal points and the beautifying agents of 
advantage records are imperative to cash related examiners. [19],[21],[23]

The benefit report moreover fuses two groupings of liabilities, current liabilities (commitments that will come due inside one year, for instance, loan boss liabilities, transient advances, and surveys) and whole deal (commitments that are normal more than one year from the date of the declaration). Liabilities are basic to financial inspectors since associations have same pledge to pay their bills reliably as individuals, while business compensation will when all is said in done be more uncertain. Whole deal liabilities are less basic to specialists, since they miss the mark on the sincerity of transient commitments, anyway their embodiment demonstrates that an association is adequately ready to be allowed to get money. [20],[22], [24]

\section{OBJECTIVES}

A.Primaryobjective

- To study about the financial performance

B. Secondry objective

- To Analyzing the past financial data for tacking the financial decision for future at

- Hi - Tech Arai Private Limited, Madurai.

- To knowledge about the financial analysis of the corporate company.

- To analyzing the original data from the company.

\section{DATA ANALYSIS AND INTERPRETATION}

Table 1 Hi-Tech Arai Private Limited 3 Years Comparative Balance Sheet

\begin{tabular}{|c|c|c|c|c|c|c|c|}
\hline Particulars & & & & \multicolumn{2}{|c|}{ Balance Difference } & \multicolumn{2}{|l|}{ Different } \\
\hline & 2013 & 2014 & 2.015 & 2.014 & 2015 & 2.014 & 2015 \\
\hline & Rs In & Rs in & Rs in & Rs in & Rs in & \multicolumn{2}{|c|}{ INCRFASESS(+) } \\
\hline I. iahilitifies & I.AKH & I.AKH & I.AKH & I.AKH & I.AKH & $\%$ & $\%$ \\
\hline & & & & & & & \\
\hline Share canital & 56000 & 56000 & 56000 & 000 & 000 & 000 & 000 \\
\hline Reserves and Sumlus & $157.71 \%$ & 171517 & 19777 & 18804 & 450659 & 12.31 & 2951 \\
\hline Net worth & 158317 & 177117 & 20337 & 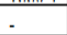 & . & . & \\
\hline \multicolumn{8}{|l|}{ Noncurrent liahilities } \\
\hline Deferred & 91844 & 68414 & 55909 & -2.343 & .35935 & .2551 & .3912 \\
\hline \multicolumn{8}{|l|}{ Current I liahilities } \\
\hline Short-term horrowings & 82.1 & - & & & -87.197 & .100 & .100 \\
\hline Trade navahles & 436703 & 441749 & $4074 ?$ & 5046 & .347 .83 & 115 & .785 \\
\hline Other mirrent liahilities & 1897.85 & 204173 & 24038 & 14887 & 51096 & 786 & 2699 \\
\hline Short term nrovisions & 1137.95 & 169878 & 22.581 & 56533 & 112572 & 4989 & 9931 \\
\hline Tontal I iahilities Chanoe & 24964.4 & 26553.3 & 29583. & 1588.8 & 4618.67 & 6.36 & 18.50 \\
\hline \multicolumn{8}{|l|}{ Assets } \\
\hline \multicolumn{8}{|l|}{ Fixed Assets } \\
\hline Tangihle assets & 901780 & 979073 & 9042.2 & 277.93 & 2,44 & 302 & 027 \\
\hline i) Intangihle assets & 000 & 18449 & 13419 & 18449 & 13419 & 0 & 0 \\
\hline iii) Canital work in & 3709 & 563 & 763 & .3146 & .2946 & .8487 & $.794)$ \\
\hline Noncurrent investments & 065 & 065 & 065 & 0 & 0 & 0 & 0 \\
\hline long term loans and & 27508 & 31477 & 2.8714 & 3969 & 12.06 & 1447 & 438 \\
\hline nther noncilment assets & 057 & 071 & 076 & 014 & 019 & 2456 & 3333 \\
\hline Noncurrent Assets & 9.331 .19 & 9796.98 & 9472.6 & 46579 & $1414 ?$ & -47.80 & 4143 \\
\hline Inventories & 5659.50 & 587356 & 472.11 & 17106 & .93071 & 302 & .1646 \\
\hline Trade receivahles & 835897 & 872564 & $9494 ?$ & 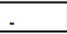 & 113534 & .159 & 1358 \\
\hline Cash and cash emilivalents & 46479 & 7057.7 & 43876 & 24048 & 3977.84 & 5173 & 84402 \\
\hline Shart term loans and & 115658 & 200099 & 147.63 & 84441 & 7.6977 & 7309 & 2332 \\
\hline Other colmrent assets & 050 & 091 & 8051 & 041 & 8001 & 87. & 160002 \\
\hline Current Assets & 1.5633 .2 & 167.56 .3 & 20110. & 11230 & 447725 & 20818 & 1686664 \\
\hline Total Assets Change & $24964 \Delta$ & 165533 & 29583 & 15888 & 161867 & 636 & 1850 \\
\hline
\end{tabular}

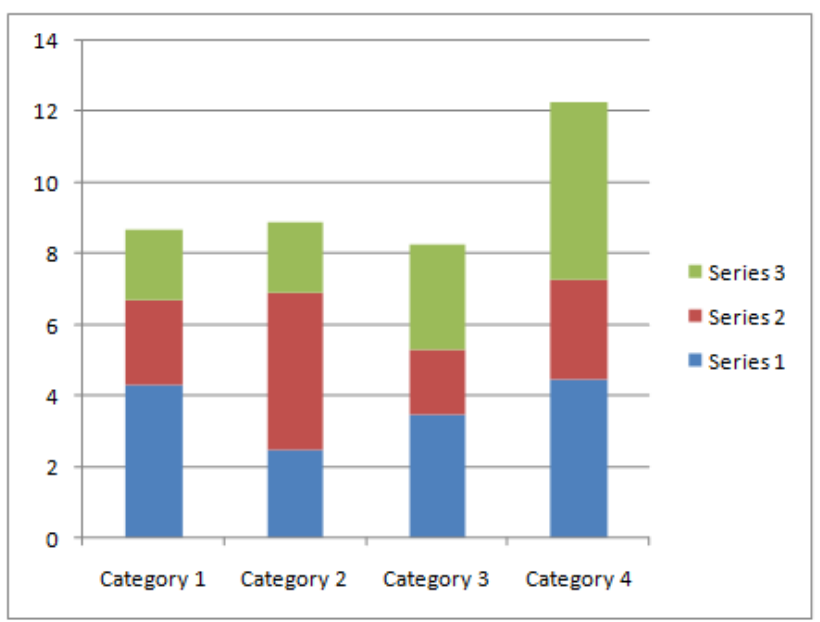

Fig:1 Comparative balance Sheet

\section{INTERPRETTION}

demonstrates that how the total assets are expanded during the year 2014, 2015, and 2016. The present resource is likewise expanded in two years $(127.64,1250.72)$ contrasted and 2014. It's Refers to the organization liquidity status of these years. Simultaneously present liabilities are diminishing of these years. It demonstrates the organization development level and current credit level of the firm. The working capital level is step by step expanded in recent years. The working capital qualities are 2014 - 4428.18 and 2015 7418.54 and 2016 [25],[27],[29]

Table:2 Comparitive Profit and Loss account Comparative profit and loss accounts (2014, 2015 and 2016)

\begin{tabular}{|c|c|c|c|c|c|c|c|c|}
\hline \multicolumn{9}{|c|}{$\begin{array}{l}\text { Hi- Tech Arai (P) L td Comparative profit and loss account } \\
\text { As on 2014, } 2015 \text { and } 2016\end{array}$} \\
\hline \multirow{3}{*}{ S.N. } & \multirow[b]{3}{*}{ Particular } & \multirow[b]{2}{*}{ 2013-14 } & \multirow[b]{2}{*}{ 2014-15 } & \multirow[b]{2}{*}{ 2015-16 } & \multicolumn{2}{|c|}{ 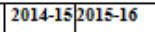 } & 2014-15 & $2015-16$ \\
\hline & & & & & \multicolumn{2}{|c|}{ Different Balance } & \multicolumn{2}{|c|}{$\begin{array}{l}\text { Different } \\
\text { percentage }\end{array}$} \\
\hline & & \begin{tabular}{|l|} 
In \\
LAKHS
\end{tabular} & in & \begin{tabular}{|l|} 
in \\
LAKHS
\end{tabular} & \begin{tabular}{|l}
\multicolumn{1}{|c}{ Rs. } \\
in \\
LAKH \\
S
\end{tabular} & in & $9 \%$ & $9 \%$ \\
\hline a) & Sales & 39864.51 & 43040.13 & 42824.63 & 3175.62 & 2960.12 & 7.96 & 7.42 \\
\hline p) & $\begin{array}{l}\text { Other } 0 . \text { Revenus } \\
\text { Total Operating }\end{array}$ & 937.16 & 963.97 & 772.08 & 26.81 & -165.08 & 2.86 & -17.61 \\
\hline 1) & Revenues & 40801.67 & 44004.1 & 43596.71 & 3202.43 & 2795.04 & 7.848 & -6.85 \\
\hline 2) & Less: cost of sales & 19287.9 & 19956.5 & 16693.82 & 668.56 & 2594.09 & 3.4662 & 13.44 \\
\hline 3) & Gross Profit & 21513.8 & 24047.7 & 26902.89 & 2533.87 & 5389.11 & 11.77 & 25.04 \\
\hline 4) & Add: Other income & 234.9 & 135.01 & 190.22 & -99.89 & -44.68 & -42.52 & -19.02 \\
\hline 5) & & 21748.7 & 24182.7 & 27093.11 & 2433.98 & 5344.43 & 11.19 & 24.57 \\
\hline 6) & Lass: Other Exp & 18264.8 & 18495.1 & 19951.38 & 230.23 & 1686.56 & 1.26 & 9.23 \\
\hline 7) & Net profit before tax & 3483.86 & 5687.61 & 7141.73 & 2203.75 & 3657.87 & 63.25 & 104.99 \\
\hline 8) & Leas: tax $\operatorname{Exp}$ & 1225.08 & 1926.15 & 2493.56 & 701.07 & 1268.48 & 57.22 & 103.54 \\
\hline 9) & Net Profit after Tax & 2258.78 & 3761.46 & 4648.17 & 1502.68 & 2389.39 & 66.52 & 105.78 \\
\hline
\end{tabular}




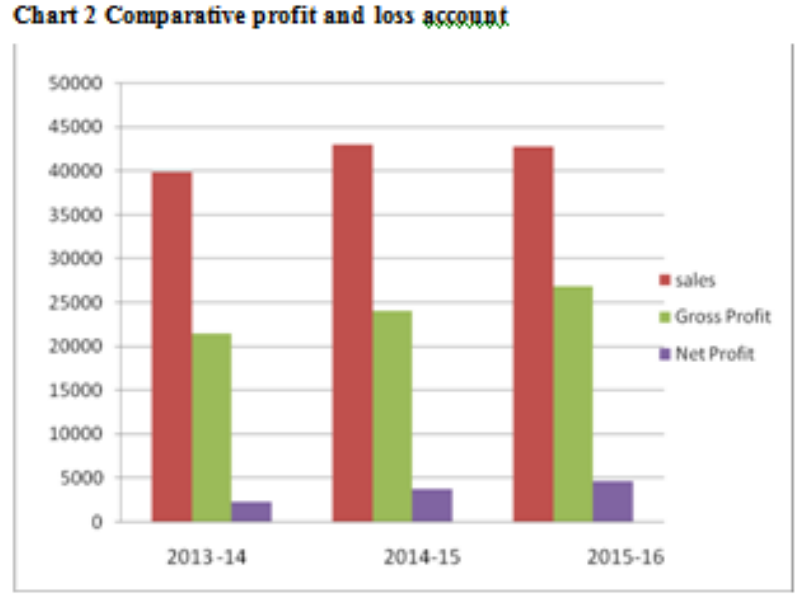

Fig:2 Comparitive Profit and Loss account

\section{INTERPRETATION}

shows on comparing the financial income statement of the company for the year ending 2014, 2015, and 2016. The total operating revenue has been increased by $25.55 \%$. But the operating expenditure has been decreased by 14.54 . So the net profit is increased by 255.16 in 2016 . The gross profit level also has been increased. It means the company has been control the production cost. The net profit level indicates the company growth level. Chart 3.2 is shows the company growth[26],[28],[30]

Table 3 Common size balance sheet $(2014,2015$ and 2016)

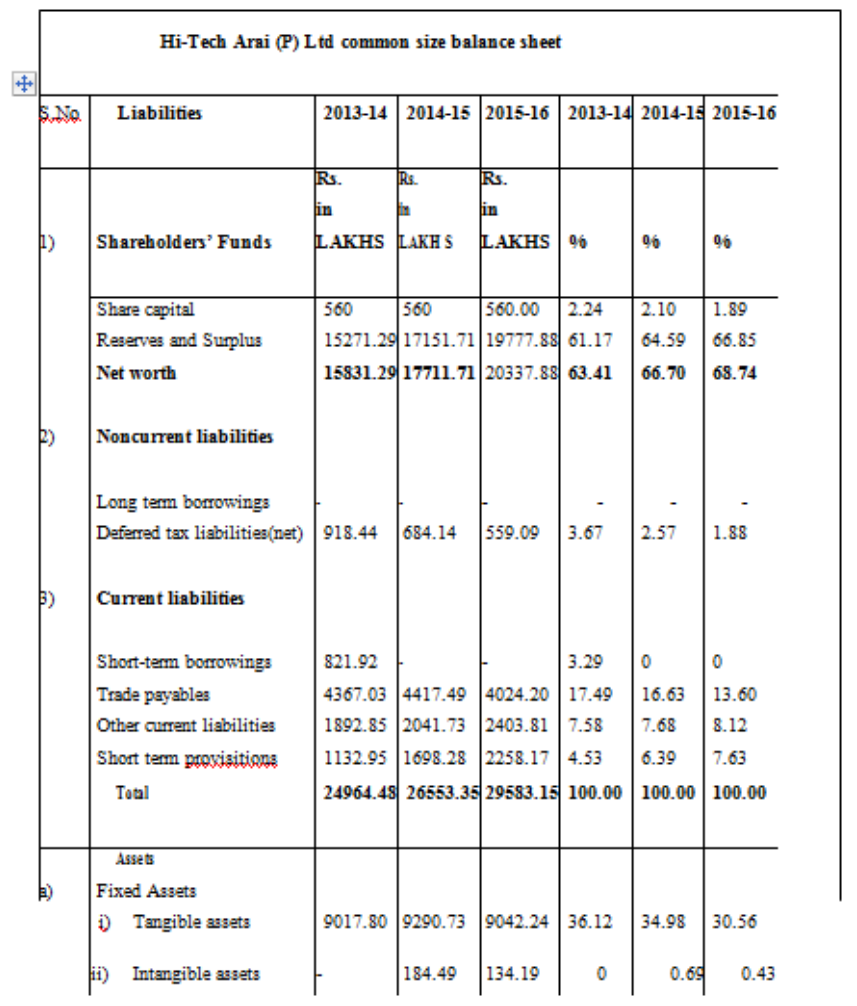
demonstrate the expanding pattern. 2015-multi year. to improve the operating revenues. countries. account to encourage the gross profit. (0.02, 0.06and0.09) in 2014, 2015 and 2016.

- The gross benefit proportions are 53.51, 53.97 and 57.82 it

- The net benefit proportion is additionally expanding pattern in last three years $(3.13,5.67$ and 8.86$)$

- The working capital turnover proportion is demonstrate the working capital improvement of the most recent three years (Rs.4428.18), (Rs.7418.54) and (Rs.8598.87)

- The costs proportion demonstrate the 2014(1\%) and 2016(0.94\%) are spare the costs yet 2015(1.01).

- The generally monetary execution is awesome in the

\section{V.DISCUSSION}

- The company correctly utilizing the current liquidity item

- The company has to improve the export of the other

- The company motivated preparing of profit and loss

- They must stabilize the growth of the organization. 


\section{CONCLUSION}

Based on information examination done on investigation of money related execution of $\mathrm{Hi}$ Tech Arai it very well may be presumed that the organization's in general budgetary exercises is attractive. Since the greater part of the crude materials are being imported, the organization needs to keep up a support stock for crisis cases. So a great deal of reserve is put resources into crude material inventories which at last influence the liquidity and benefit of the worry and consequently the liquidity pattern of the organization is expanding step by step which is a decent marker. The organization the greater part of incomes from the fare things of different nations. They will urging the fare to the remote counters. The money and bank parity of the organization is declining so the organization must have an eye on it. Installment to the lenders is deferred because of the inaccessibility of money close by.

\section{REFERENCES}

1. G BharthVajan R., Ramachandran S.,Psychographic dimensions of training,2016,International Journal of Pharmacy and Technology,V-8,I-4,P-23727-23729

2. Balakrishnan P., Bharthvajan R.,A study on human resource planning in hospitals in Chennai City,2014,International Journal of Applied Engineering Research,V-9,I-22,P-7503-7507

3. Priyadarsini P., Bharthvajan R.,Role of emotional intelligence training programme in reducing the stress of the nurses,2014,International Journal of Applied Engineering Research,V-9,I-22,P-7411-7421

4. Kerinab Beenu G., Bharthvajan R.,Empirical analysis on the cosmetic buying behavior of young women in South India,2014,International Journal of Applied Engineering Research,V-9,I-22,P-7361-7366

5. Balakrishnan P., Bharthvajan R.,Whistling in the wind,2014,International Journal of Applied Engineering Research,V-9,I-22,P-7586-7593

6. Krishnan B., Peter M.,Health hazards of Indian Bpo employee-an alarming issue,2014,International Journal of Applied Engineering Research,V-9,I-22,P-7336-7341

7. Kerinab Beenu G.H., Peter M.,Role of insurance in economic development,2014,International Journal of Applied Engineering Research,V-9,I-22,P-7532-7539

8. Balakrishnan P., Peter M., Priyadarsini P.,Efficiency of safety measures for wellbeing of employees in manufacturing industry,2014,International Journal of Applied Engineering Research,V-9,I-22,P-7376-7382

9. Anbarasi M., Praveen Kumar S.,Online sales promotions of herbal products and its effectiveness towards tanisha.com,2019,Indian Journal of Public Health Research and Development,V-10,I-1,P-195-200

10. Anbarasi M., Praveen Kumar S.,Various online marketing and promotions strategies to improve the validation towards the organic products in the pharmaceutical sectors,2019,Indian Journal of Public Health Research and Development,V-10,I-1,P-263-269

11. Loganathan R., Praveen Kumar S.,Grievance handling a key factor for solving issues of employees in an organization,2014,International Journal of Applied Engineering Research,V-9,I-22,P-7483-7491

12. Loganathan R., Praveen Kumar S.,Study on preference of private label brands in super and Hypermarkets,2014,International Journal of Applied Engineering Research,V-9,I-22,P-7327-7335

13. Smitha M., Praveen Kumar S.,Understanding stress and its managementamong the nurses in Chennai city,2014,International Journal of Applied Engineering Research,V-9,I-22,P-7560-7565

14. Kerinab Beenu G.H., Praveen Kumar S.,A study on the investment behavior of Chennai investors in mutual fund schemes,2014,International Journal of Applied Engineering Research,V-9,I-22,P-7520-7525

15. Loganathan R., Praveen Kumar S.,Retention strategies key for organizational productivity,2014,International Journal of Applied Engineering Research,V-9,I-22,P-7443-7447

16. Pavithra J., Ganesan M., Brindha G.,State wise analysis of microfinance sector in India,2016,International Journal of Pharmacy and Technology,V-8,I-4,P-23417-23432

17. Pavithra J., Ganesan M.,A comparative study on microfinance in India and abroad,2016,International Journal of Applied Business and Economic Research,V-14,I-8,P-5471-5476
18. Pavithra J., Ganesan M.,A study on awareness and impact of micro-financial schemes,2016,International Journal of Applied Business and Economic Research,V-14,I-8,P-5449-5460

19. Senthilmurugan P., Pavithra J.,Consumer preference towards organised retailing with reference to Big Bazaar,2014,International Journal of Applied Engineering Research,V-9,I-22,P-7469-7475

20. Senthilmurugan P., Pavithra J.,Implication of social media marketing in growing healthcare industry,2014,International Journal of Applied Engineering Research,V-9,I-22,P-7448-7456

21. Loganathan R., Pavithra J.,Consumer perception towards private label brand over other brands in super markets and hypermarkets,2014,International Journal of Applied Engineering Research,V-9,I-22,P-7355-7360

22. Kerinab Beenu G., Pavithra J.,Tradeâ€"off between liquidity and profitability in logistics industry,2014,International Journal of Applied Engineering Research,V-9,I-22,P-7398-7401

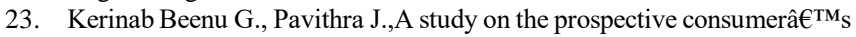
perception towards utility cars in Chennai city,2014,International Journal of Applied Engineering Research,V-9,I-22,P-7526-7531

24. Pavithra J., Dilli Babu P., Ambuli T.V.,A study on budgetary control at Maruti Service Masters, Chennai,2014,International Journal of Applied Business and Economic Research,V-12,I-2,P-151-161

25. Pavithra J., Dilli Babu P., Ambuli T.V.,A study on customer satisfaction of retro Garments Pvt Ltd, Chennai,2014,International Journal of Applied Business and Economic Research,V-12,I-2,P-381-391

26. Kerinab Beenu G.H., Pavithra J., Senthilmurugan P.,A study on the influence of promotional activities for TATA ARIA among consumers in Chennai,2014,International Journal of Applied Engineering Research,V-9,I-22,P-7572-7578

27. Vijayaragavan S.P.,An investigative expert that's general FBG sensors,International Journal of Mechanical Engineering and Technology,V-8,I-8,PP-1500-1505,Y-2017

28. Vijayaragavan S.P.,Equalization routing protocol for Wi-Fi sensor strategy,International Journal of Mechanical Engineering and Technology,V-8,I-8,PP-1662-1666,Y-2017

29. Karthik B., Kiran Kumar T.V.U., Vijayaragavan P., Bharath Kumaran E.,Design of a digital PLL using 0.35 ̂̂1/4m CMOS technology,Middle East Journal of Scientific Research,V-18,I-12,PP-1803-1806,Y-2013

30. Kanniga E., Selvaramarathnam K., Sundararajan M.,Kandigital bike operating system,Middle - East Journal of Scientific Research, V

31. Jasmin M., Vigneshwaran T., Beulah Hemalatha S.,Design of power aware on chip embedded memory based FSM encoding in FPGA,International Journal of Applied Engineering Research,V-10,I-2,PP-4487-4496,Y-2015

32. Jasmin M.,Optimization techniques for low power VLSI circuits,Middle East Journal of Scientific Research,V-20,I-9,PP-1082-1087,Y-2014

33. Jasmin M., Vigneswaran T.,Fuzzy controller for error control of on - Chip communication,2017 International Conference on Algorithms, Methodology, Models and Applications in Emerging Technologies, ICAMMAET 2017,V-2017-January,I-,PP-1-5,Y-2017

\section{AUTHORS PROFILE}

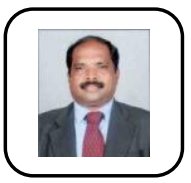

Ramamoorthy Assistant Professor ,Department of MBA, Bharath Institute of Higher Education and Research, Tamilnadu, India

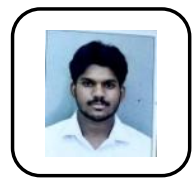

G.Thilrukshan Student ,Department of MBA, Bharath Institute of Higher Education and Research, Tamilnadu, India



Vimala D Assistant Professor ,Department of CSE, Bharath Institute of Higher Education and Research, Tamilnadu, India 